\title{
Persepsi Masyarakat terhadap Manfaat Lansekap Mangrove Center Tuban Kabupaten Tuban Provinsi Jawa Timur
}

\author{
DIMAS SAIKHU RAHMAN ${ }^{*}$, NANIEK KOHDRATA2 IDA AYU MAYUN ${ }^{1}$
}

1Program Studi Agroekoteknologi, Fakultas Pertanian, Universitas Udayana

2Program Studi Arsitektur Pertamanan, Fakultas Pertanian, Universitas Udayana

*Email: naniek_kohdrata@unud.ac.id

\section{ABSTRACT \\ A Public Perception towards Benefits of the Landscape of Mangrove Center Tuban Tuban Regency - East Java Province}

This research was motivated by the problems that are often experienced by the manager of Mangrove Center Tuban changing the function of the region in this area which is the Environmental Educatian Center. This research uses descriptive qualitative approach with case studies in order to capture the phenomena that exist in the field then studied more deeply. The highest perception of knowledge of the benefits and advantages of mangrove forests in Mangrove Center Tuban rated public of the environmental aspects of the lowest $40 \%$ and the perception that the social aspects of the environment of $3 \%$. Highest perception Mangrove Center Tuban by $40 \%$ of respondents perceived as the cultivation of mangrove and lowest perception is envorinmental education center at $14 \%$. The highest perception of respondents stated assess the mangrove forests of the aspects of a life by $63 \%$ and the lowest was the respondent state on the features and functions of mangrove forests of $3 \%$. The highest expression of respondents said getting information from the mass media by $37 \%$ and the lowest statement from the manager only by $29 \%$. The conclusion of this study is the public perception of mangrove forests Mangrove Center Tuban is people just look at the circumstances that they see without looking for information first.

Keywords: perception, landscape, mangrove, Mangrove Center Tuban

\section{Pendahuluan}

Kabupaten Tuban adalah salah satu kabupaten yang ada di propinsi Jawa Timur memiliki panjang garis pantai $65 \mathrm{~km}$ dan memiliki sebaran hutan mangrove 120,40 $\mathrm{Ha}$ (BPS Tuban, 2013). Mangrove Center Tuban terletak di barat ibukota Kabupaten Tuban di Jalan Tuban - Semarang Km 9 Desa Jenu, Kecamatan Jenu, Kabupaten Tuban. Sebelumnya daerah pantai Jenu merupakan salah satu daerah yang terkena dampak limbasan ombak besar yang mengakibatkan kerusakan tanah sampai mencapai jalan raya Pantura (Pantai Utara). Sejak masyarakat telah merehabilitasi Pantai Jenu, pantai tersebut telah menjadi kawasan yang hijau dan indah di pesisir pantai Kabupaten Tuban. Dengan telah berubahnya wajah lansekap pantai Jenu tersebut menjadikan kawasan ini mulai 
dikenal oleh masyarakat luas yang berasal dari Kabupaten Tuban sendiri maupun dari kabupaten lainnya yang berada di sekitar Kabupaten Tuban.

Keberadaan masyarakat di dalam maupun di sekitar kawasan hutan mangrove di Mangrove Center Tuban merupakan bagian yang tidak terpisahkan dari pemanfaatan ekosistem hutan magrove. Permasalahan yang kerap dialami oleh pengelola atau yang dalam hal ini adalah Mangrove Center Tuban yaitu berubahnya fungsi kawasan di daerah ini yang merupakan Pusat Pendidikan Lingkungan Hidup. Keberadaan Mangrove Center Tuban ini menjadi multifungsi, tidak hanya sebagai kawasan Pusat Pendidikan Lingkungan Hidup akan tetapi juga tempat untuk kegiatan-kegiatan yang menarik minat masyarakat. Kegiatan tersebut seperti berdagang, berwisata maupun melakukan kegiatan interaksi sosial, sehingga dilansekap ini telah terjadi perbedaan persepsi dikalangan masyarakat. Masyarakat lebih mengetahui kawasan mangrove di Mangrove Center Tuban sebagai tempat wisata dan mencari nafkah dibanding sebagai kawasan rehabilitasi lingkungan dan Pusat Pendidikan Lingkungan Hidup. Rumusan masalah dari penelitian ini adalah pertaman mengenai pengetahuan masyarakat tentang manfaat dan keuntungan dengan adanya mangrove di Mangrove Center Tuban, kedua mengenai persepsi masyarakat tentang Mangrove Center Tuban, ketiga mengenai persepsi masyarakat terhadap mangrove di kawasan Mangrove Center Tuban. Sedangkan tujuan penelitian adalah 1) untuk mengetahui sejauh mana pengetahuan masyarakat tentang manfaat dan keuntungan mangrove di Mangrove Center Tuban, 2) untuk mengetahui persepsi masyarakat tentang Mangrove Center Tuban, 3) untuk mengetahui persepsi masyarakat terhadap mangrove di Mangrove Center Tuban. Manfaat yang diharapkan dari penelitian ini adalah sebagai sumber informasi kepada pihak pengelola atau pihak terkait tentang alternatif pengelolaan lansekap dan pengembangan Mangrove Center Tuban yang berada di kawasan pesisir pantai Desa Jenu Kecamatan Jenu, Kabupaten Tuban. Kerangka piker penelitian seperti terlihat pada Gambar 1.

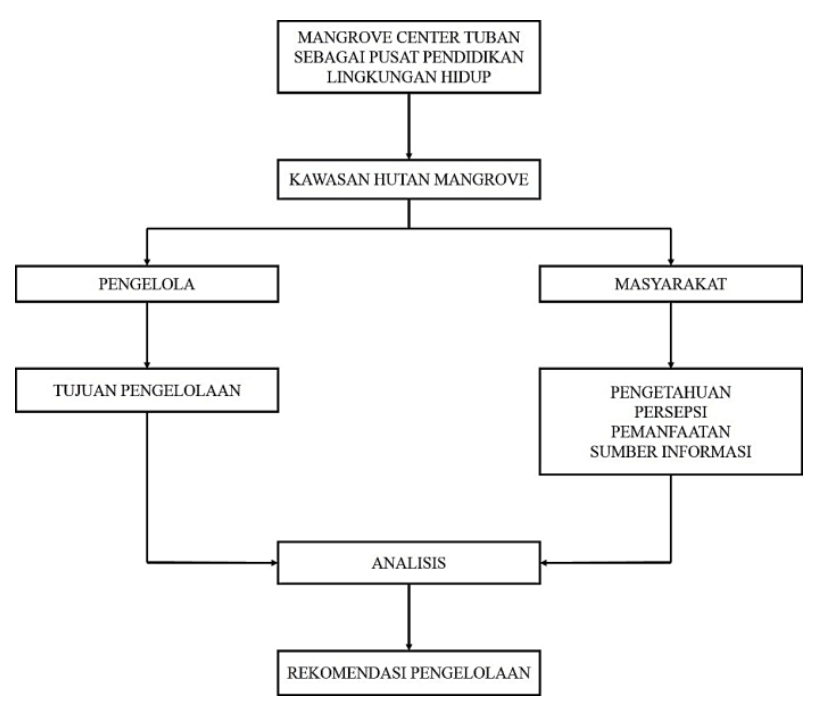

Gambar 1. Kerangka pikir penelitian 
Perkembangan Mangrove Center Tuban sebagai kawasan Pusat Pendidikan Lingkungan Hidup, menjadi alasan untuk dikelolanya lansekap guna menunjang kegiatan dan aktivitas masyarakat. Pengelolaan diperlukan untuk menjaga kondisi ruang dan menambah pengetahuan masyarakat tentang Mangrove Center Tuban sebagai Pusat Pendidikan Lingkungan Hidup agar tidak disalah gunakan pemanfaatannya oleh masyarakat. Pelaksanaan kegiatan pengelolaan tersebut tidak hanya didasarkan oleh keinginan dari pihak pengelola saja, tetapi juga berdasarkan tanggapan dan pengetahuan masyarakat sebagai pengguna tapak. Penelitian ini dilakukan untuk lebih mengetahui kondisi akan pemanfaatan mangrove oleh masyarakat. Oleh karena itu perlu diketahui persepsi masyarakat terhadap pemanfaatan untuk rekomendasi pengelolaan Mangrove Center Tuban yang berbasis kemasyarakatan.

\section{Metodologi}

\subsection{Tempat dan Waktu Penelitian}

Penelitian dilaksanakan sejak bulan April 2015 sampai Maret 2016.

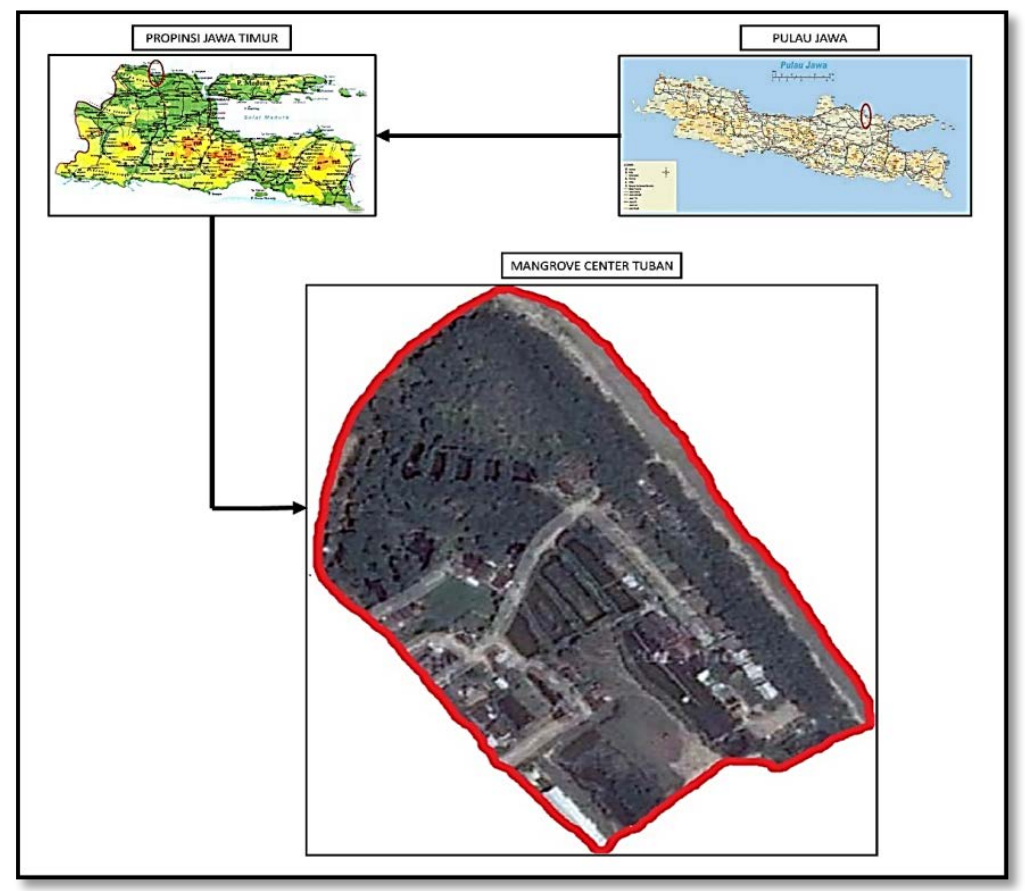

Gambar 2. Lokasi Penelitian

\subsection{Bahan dan Alat}

Bahan dan alat penelitian yang digunakan untuk pengumpulan data dalam penelitian ini adalah lembar pedoman wawancara, kamera digital, perekam suara dan komputer dengan softwareMicrosoft Word.

\subsection{Batasan Studi}

Lokasi penelitian dibatasi hanya pada areal Mangrove Center Tuban. Studi penelitian dibatasi pada persepsi masyarakat terhadap kawasan Mangrove Center Tuban. Persepsi yang dicari adalah dari masyarakat yang ada pada saat penelitian. 


\subsection{Bentuk Penelitian}

Penelitian ini menggunakan penelitian kualitatif karena dengan bentuk penelitian ini memungkinkan peneliti untuk dapat menggambarkan objek penelitian secara holistik berdasarkan realitas sosial yang ada di lapangan. Sutopo (2010) mengatakan bahwa penelitian kualitatif adalah suatu kegiatan untuk menjawab berbagai pertanyaan tentang bagaimana dan mengapa. Sesuai dengan karakteristik data yang bersifat kualitatif maka analisa akan dilakukan secara deskriptif.

\subsubsection{Data Penelitian}

Sutopo, (2010) mengatakan bahwa sumber data dalam penelitian kualitatif secara menyeluruh berupa narasumber atau responden; peristiwa atau aktivitas; tempat atau lokasi; benda, beragam gambar dan rekaman; dokumen dan arsip. Dari berbagai sumber data tersebut beragam informasi dapat digali untuk menjawab dan memahami masalah yang telah dirumuskan. Adapun sumber data yang digunakan dalam penelitian ini adalah sumber data primer dan sumber data sekunder.

\subsubsection{Teknik Pemilihan Responden}

Dalam penelitian ini peneliti memilih responden yaitu 1 pengelola sebagai responden tentang tujuan, data biofisik dan sejarah Mangrove Center Tuban serta 35 masyarakat yang ada pada saat dilakukan. Responden penelitian diambil di lingkungan Mangrove Center Tuban yang dilakukan pada saat siang dan sore hari dimana saat masyarakat banyak berkunjung.

\subsubsection{Teknik Pengumpulan Data}

Pengumpulan data merupakan bagian yang sangat penting dalam setiap kegiatan penelitian. Hal tersebut dilakukan untuk mendapatkan data yang akurat, terperinci dan dapat dipercaya serta dapat dipertanggungjawabkan.

\subsubsection{Analisis Data}

Analisis data menurut Moleong (2007) merupakan suatu proses pengorganisasian dan pengurutan data kedalam pola, kategori, dan satuan uraian dasar sehingga dapat ditemukan tema dan dirumuskan hipotesis kecil yang disarankan pola data. Analisis data yang digunakan dalam penelitian ini adalah model analisis interaktif (Interactive Model of Analisys) yang memiliki tiga komponen yaitu: reduksi data, penyajian data dan penarikan kesimpulan serta verifikasinya.

\section{Hasil dan Pembahasan}

\subsection{Pengetahuan Masyarakat Tentang Manfaat dan Keuntungan Hutan Mangrove di Mangrove Center Tuban}

Berdasarkan hasil wawancara (Gambar 3), persepsi tertinggi pengetahuan manfaat dan keuntungan hutan mangrove di Mangrove Center Tuban dinilai masyarakat dari aspek lingkungan sebesar 40\%. Sesuai dengan hasil observasi di lapang, aspek lingkungan adalah aspek yang paling banyak diungkapkan oleh responden karena Mangrove Center Tuban berdiri didasari oleh keprihatinan salah seorang warga terhadap lingkungan di sekitar tempat tinggalnya. Dengan perubahan lansekap yang terjadi tersebut, mengakibatkan masyarakat yang tinggal di sekitar hutan mangrove merasakan sendiri 
manfaat yang begitu besar dari adanya hutan mangrove di Mangrove Center Tuban ini yaitu dengan tidak terjadinya bencana banjir rob yang diakibatkan oleh naiknya permukaan air laut.

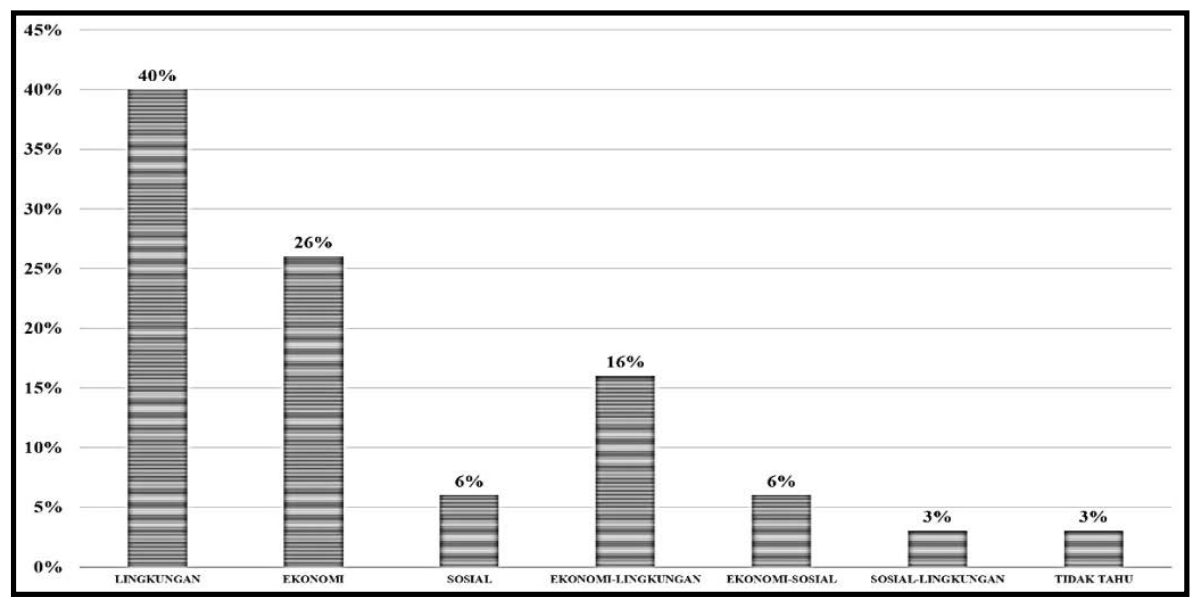

Gambar 3. Persepsi Masyarakat tentang Manfaat dan Keuntungan Mangrove di Mangrove Center Tuban

Masyarakat menilai dan menyatakan bahwa juga terjadi aspek sosial lingkungan yang terjadi di kawasan ini sebesar 3\%. Aspek ini merupakan aspek terendah yang diungkapkan oleh responden. Aspek sosial lingkungan dinilai masyarakat dari pengalaman masyarakat tersebut. Hal yang dimaksud dengan lingkungan dari aspek sosial lingkungan ini adalah dari pandangan terhadap kawasan hutan mangrove di Mangrove Center Tuban ini menjadi destinasi wisata sekaligus tempat untuk belajar tentang lingkungan. Hal tersebut dikarenakan selain di dalam kawasan hutan mangrove, di sekitar atau di dalam kawasan Mangrove Center Tuban juga terdapat perpustakan yang berisi tentang buku-buku yang mengajarkan tentang lingkungan. Masyarakat mendapatkan informasi tentang hutan mangrove dan informasi tentang bagaimana menjaga lingkungan dan memanfaatkan lingkungan sekitar dari perpustakan tersebut.

Identifikasi terhadap pengetahuan masyarakat terhadap fungsi hutan mangrove di Mangrove Center Tuban dapat dibagi menjadi enam zona. Setiap zona menggambarkan pengetahuan masyarakat akan manfaat dan keuntungan hutan mangrove. Zona lingkungan pada kawasan Mangrove Center Tuban teridentifikasi berada pada kawasan hutan mangrove dan lokasi pembibitan hutan mangrove. Zona sosial teridentifikasi pada kawasan lapak dan gazebo yang ada pada kawasan tersebut. Zona ekonomi teridentifikasi pada kawasan bumi perkemahan yang dimanfaatkan oleh masyarakat untuk berdagang. Zona ekonomi - lingkungan teridentifikasi berada diantara lokasi pembibitan dan bumi perkemahan. Untuk zona ekonomi - sosial teridentifikasi berada pada sekitar gazebo yang terdapat pada area bumi perkemahan. Dan zona sosial - lingkungan teridentifikasi berada disekitar kantor dan perpustakaan. Berdasarkan zona tersebut dapat diketahui bagaimana masyarakat menilai manfaat dan keuntungan hutan mangrove yang ada di kawasan Mangrove Center Tuban (Gambar 4). 


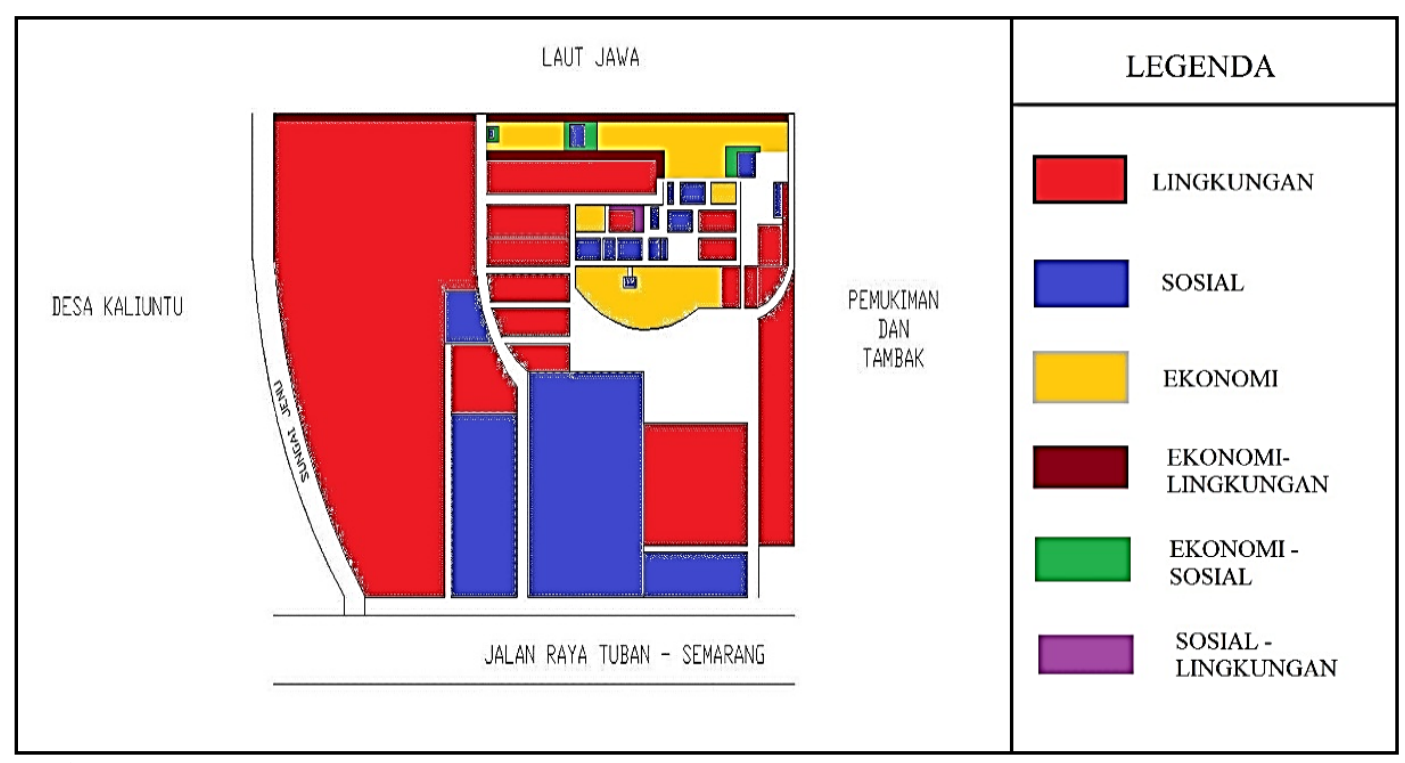

Gambar 4. Zonasi Pengetahuan Masyarakat tentang Manfaat dan Keuntungan Hutan Mangrove

di Mangrove Center Tuban

Informasi dan pengetahuan tentang hutan mangrove dapat menjadi atau merupakan bagian dari pendidikan lingkungan. Pendidikan lingkungan khususnya lingkungan pesisir sangat dibutuhkan, karena dapat menyangkut kehidupan sehari - hari masyarakat. Pada dasarnya pengetahuan dalam pendidikan lingkungan pesisir adalah suatu informasi mengenai persoalan bagaimana menjaga kawasan pesisir dapat menjaga maupun dimanfaatkan oleh masyarakat. Salah satunya adalah kawasan hutan mangrove di Mangrove Center Tuban.

\section{a. Persepsi Masyarakat terhadap Pemanfaatan Mangrove Center Tuban}

Mangrove Center Tuban oleh 40\% responden dipersepsikan sebagai tempat pembudidayaan mangrove. Persepsi ini adalah persepsi tertinggi yang dikemukakan oleh para responden. Responden menyatakan hal tersebut dikarenakan oleh pengetahuan masyarakat yang melihat banyaknya bibit-bibit hutan mangrove di dalam kawasan Mangrove Center Tuban ini. Pembudidayaan mangrove di dalam kawasan ini merupakan salah satu kegiatan yang dilaksanakan pengelola untuk memenuhi permintaan pesanan bibit-bibit hutan mangrove dari daerah lain yang ingin melakukan konservasi hutan mangrove. Selain untuk didistribusikan ke daerah lain, bibit hutan mangrove tersebut juga ditanam oleh pengelola di sekitar kawasan Mangrove Center Tuban untuk memperluas kawasan hutan mangrove.

Responden yang menyatakan Mangrove Center Tuban adalah pusat pendidikan lingkungan hidup sebesar 14\%, aspek ini adalah aspek terendah yang diungkapkan oleh responden. Berdasarkan hasil survey masyarakat yang menyatakan Mangrove Center Tuban merupakan pusat pendidikan lingkungan hidup adalah masyarakat yang tinggal di sekitar kawasan Mangrove Center Tuban. Mereka mengetahuinya dari sosialisasi yang dilakukan oleh pengelola kepada masyarakat sekitar. Masyarakat menilai Mangrove Center Tuban dikatakan sebagai pusat pendidikan lingkungan hidup dikarenakan di 
kawasan ini sering ada kegiatan lingkungan yang dilaksanakan oleh pengelola dan masyarakat sekitar. Masyarakat juga menilai dengan dijadikannya Mangrove Center Tuban ini sebagai pusat pendidikan lingkungan hidup, maka masyarakat mendapatkan informasi yang benar tentang adanya konservasi hutan mangrove di kawasan ini yang dapat dimanfaatkan secara positif oleh masyarakat sekitar.

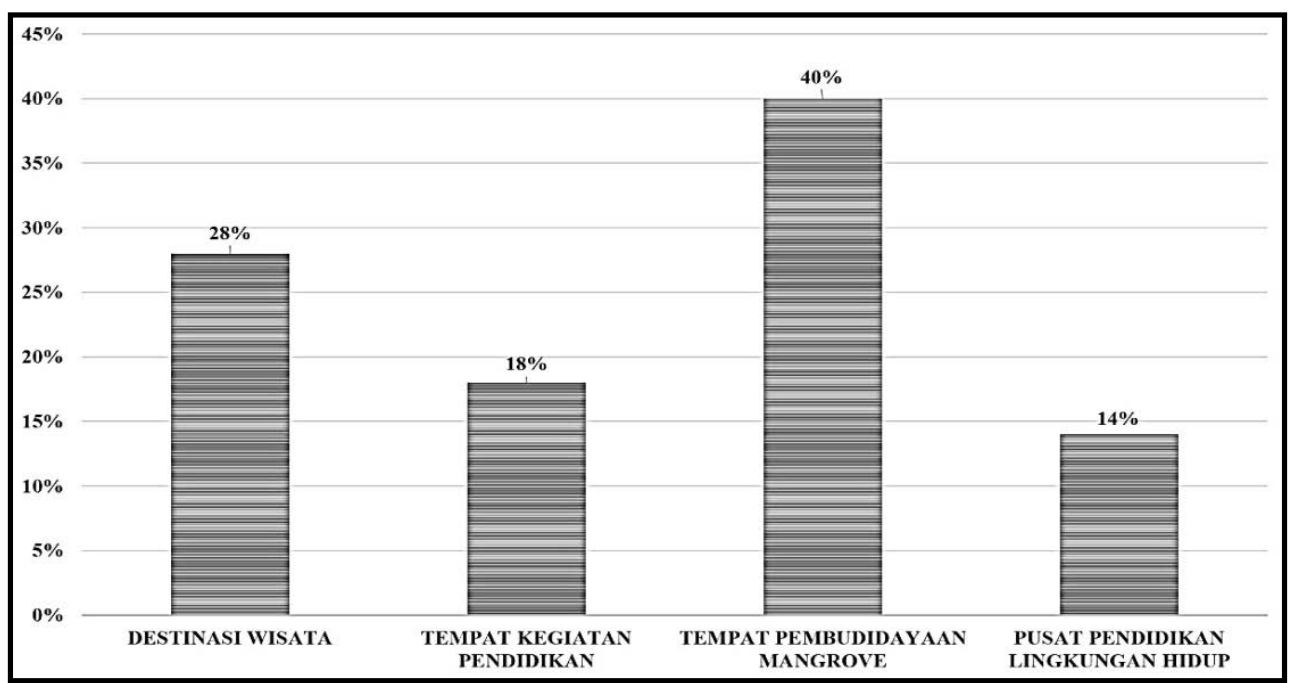

Gambar 5. Persepsi Masyarakat terhadap Pemanfaatan Mangrove Center Tuban

Dengan demikian dapat disimpulkan bahwa pandangan maupun persepsi seseorang khususnya masyarakat yang masuk ke dalam kawasan Mangrove Center Tuban bermacam-macam. Dari keberagaman persepsi masyarakat tentang Mangrove Center Tuban tentunya setiap orang mempunyai pandangannya masing-masing yang bisa berbeda-beda. Perbedaan persepsi tergantung dari latar belakang, pengalaman dan informasi yang diterima oleh orang yang bersangkutan. Masyarakat mengartikan Mangrove Center Tuban sebagai suatu kawasan yang dimana terdapat transfer pengetahuan tentang lingkungan, sehingga mereka dapat mengetahui segala sesuatu yang berhubungan dengan lingkungan. Hal ini sesuai dengan pendapat Walgito (2003: 46) menyatakan bahwa, ada dua faktor yang mempengaruhi persepsi antara lain: faktor internal dan faktor eksternal. Faktor internal adalah faktor yang ada dalam individu itu sendiri, seperti perasaan, pengalaman, kemampuan berfikir, dan kerangka acuan. Sedangkan faktor eksternal adalah faktor stimulus itu sendiri dan faktor lingkungan dimana persepsi itu berlangsung.

\section{b. Persepsi Masyarakat terhadap Hutan Mangrove di Mangrove Center Tuban}

Berdasarkan survei dan wawancara dengan para responden ditemukan bahwa bentuk-bentuk persepsi masyarakat terhadap mangrove di kawasan Mangrove Center Tuban yang diketahui masyarakat yaitu tempat hidup, fisik, dan fungsi mangrove. Berdasarkan wawancara, maka dapat diidentifikasi bentuk-bentuk persepsi masyarakat terhadap mangrove di kawasan Mangrove Center Tuban yaitu: (1) Tempat hidup, (2) Fisik, dan (3) Fungsi. 
Berdasarkan hasil wawancara (Gambar 6), didapatkan persepsi yang paling tinggi responden menyatakan menilai hutan mangrove dari aspek tempat hidupnya sebesar $63 \%$. Hutan mangrove merupakan jenis tumbuhan yang halofit yaitu hutan mangrove dapat tumbuh di area yang tergenang dan mengandung kadar garam. Masyarakat juga menilai sama dengan pernyataan tersebut, masyarakat menilai hutan mangrove yang ada di kawasan Mangrove Center Tuban ini adalah tumbuhan yang hidup di pantai dan air tergenang. Hal tersebut diungkapkan para responden dikarenakan hutan mangrove di Mangrove Center Tuban ini hidup di area pertemuan antara sungai Jenu dengan Laut Jawa.

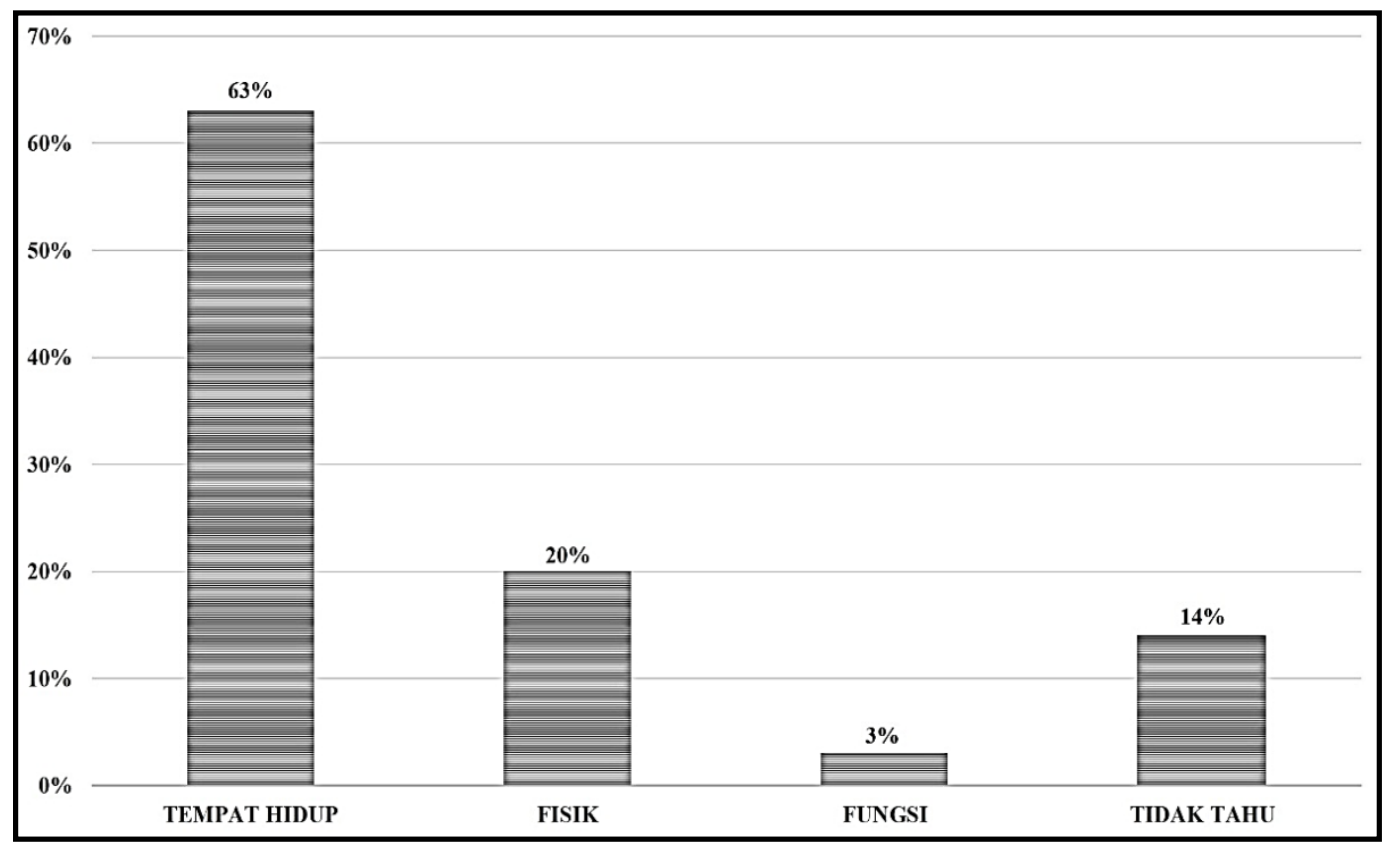

Gambar 6. Persepsi Masyarakat terhadap Hutan Mangrove di Mangrove Center Tuban

Berdasarkan hasil wawancara, diperoleh bahwa pernyataan responden yang terendah adalah responden yang menyatakan pengetahuannya tentang hutan mangrove yaitu dari aspek fungsi hutan mangrove sebesar 3\%. Fungsi hutan mangrove yang dimaksud adalah ekosistem hutan mangrove dinilai sebagai dinding alami untuk menahan ombak besar supaya air laut tidak naik ke daratan maupun kepemukiman.

Pengetahuan masyarakat akan kawasan hutan mangrove di Mangrove Center Tuban masih terhitung rendah. Pengalaman tentang apa yang dilihat dan apa yang dirasakan adalah pengetahuan dan informasi yang benar bagi masyarakat. Sedangkan aspek fungsi dari hutan mangrove begitu banyak, akan tetapi fungsi yang dirasakan seperti saat ini yaitu tidak terjadinya banjir rob adalah pengetahuan bagi masyarakat.

\section{c. Sumber Informasi Masyarakat tentang Hutan Mangrove di Mangrove Center Tuban}

Berdasarkan wawancara, maka dapat diidentifikasi sumber informasi masyarakat tentang mangrove di kawasan Mangrove Center Tuban yaitu: (1) Pengelola, (2) Media massa, dan (3) Masyarakat. Berdasarkan hasil wawancara (Gambar 7) didapatkan pernyataan tertinggi yaitu responden menyatakan mendapatkan informasi dari media 
massa sebesar $37 \%$. Media massa digunakan sebagai sumber untuk memperoleh informasi tentang hutan mangrove. Masyarakat lebih sering memperoleh berbagai informasi dan pengetahuan tentang hutan mangrove dari media massa baik media cetak seperti koran, majalah, brosur, baliho dan buku maupun dari media elektronik seperti televisi dan internet karena pada dasarnya mereka mendapatkan sedikit informasi tentang hutan mangrove dari pengelola. Pengelola lebih aktif di media elektronik dan tulisan dalam baliho maupun brosur daripada berkomunikasi dan bersosialisasi secara langsung dengan masyarakat ataupun pengunjung.

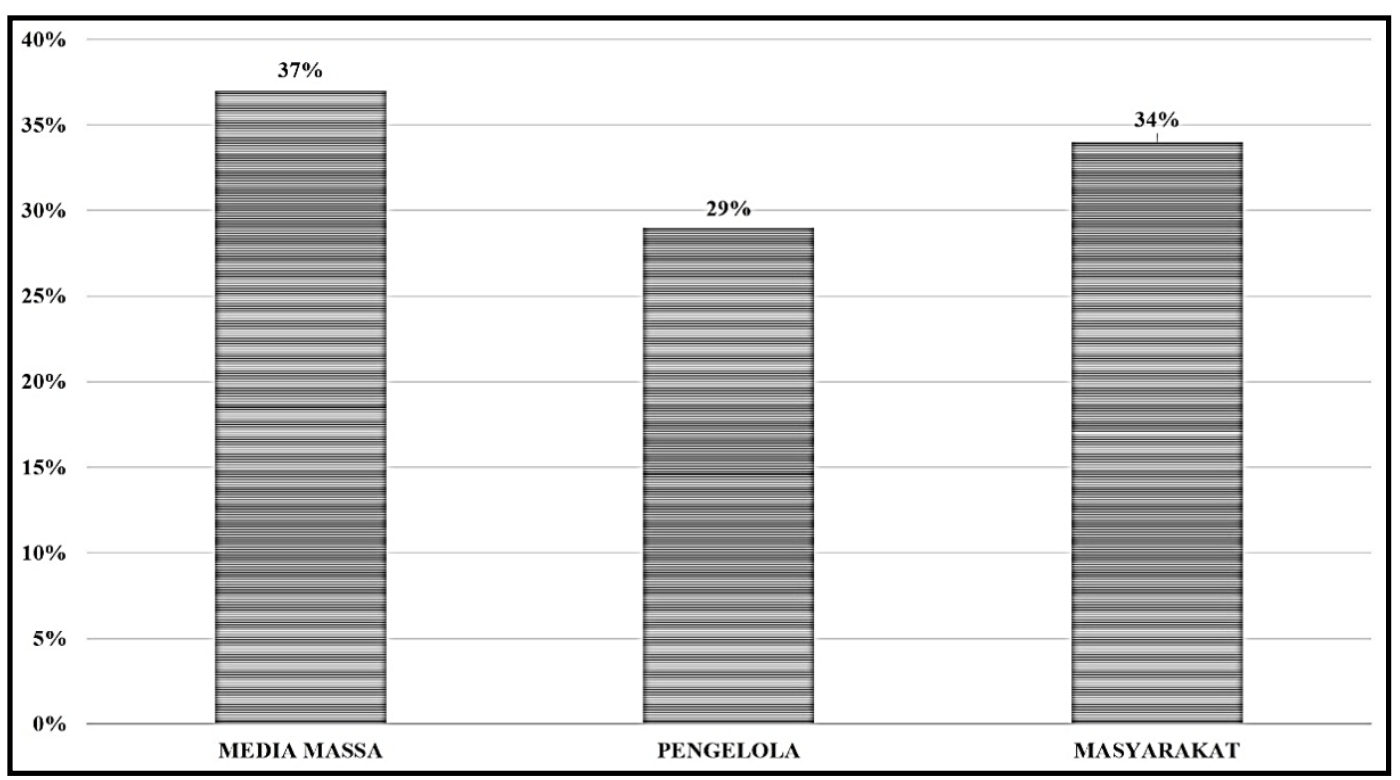

Gambar 7. Sumber Informasi Masyarakat tentang Mangrove

Berdasarkan hasil wawancara, diperoleh pernyataan terendah masyarakat yang mendapatkan informasi dari pengelola hanya sebesar 29\%. Sama halnya dengan media massa dan masyarakat, pengelola Mangrove Center Tuban juga berupaya untuk memberikan informasi tentang hutan mangrove di Mangrove Center Tuban. Dengan menggunakan media massa seperti, baliho, brosur maupun website telah dibuat pengelola untuk memberikan informasi tentang hutan mangrove.

Anggapan sebagian besar masyarakat bahwa hutan mangrove adalah hal yang berkaitan dengan tempat wisata hal ini dikarenakan oleh dibenak mereka ketika mendengar kata hutan mangrove selalu diasosiasikan dengan pantai dan kawasan hutan mangrove lainnya. Sebagian besar masyarakat kita mengidentikkan hutan mangrove dengan tempat wisata. Hutan mangrove diartikan dengan tempat wisata dan tempat kegiatan lingkungan dengan hutan mangrove. Pandangan keliru semacam itu yang akhirnya menimbulkan anggapan kalau hutan mangrove itu sebagai tempat wisata dan melakukan kegiatan sehingga membicarakan tentang hutan mangrove sebagai tempat wisata itu hal yang relevan dengan apa yang didapat dari informasi lainnya. 


\section{Simpulan dan Saran}

\subsection{Simpulan}

1. Pada dasarnya pengetahuan dalam pendidikan lingkungan pesisir adalah suatu informasi mengenai persoalan bagaimana menjaga kawasan pesisir dapat menjaga maupun dimanfaatkan oleh masyarakat.

2. Persepsi masyarakat mengenai pemanfaatan Mangrove Center Tuban adalah masyarakat mengartikan Mangrove Center Tuban sebagai suatu kawasan yang dimana terdapat proses transfer pengetahuan lingkungan dengan tujuan untuk membekali individu sehingga dapat mengetahui hal-hal yang berhubungan dengan lingkungan.

3. Persepsi masyarakat terhadap hutan mangrove di Mangrove Center Tuban adalah masyarakat hanya melihat situasi dan kondisi yang mereka lihat tanpa mencari informasi terlebih dahulu.

4. Sumber informasi tentang hutan mangrove yang digunakan oleh masyarakat adalah media massa dan komunikasi sesama masyarakat sebagai sumber informasi tentang hutan mangrove karena pada umumnya mereka tidak mendapatkan informasi dari pengelola Mangrove Center Tuban. Sumber informasi tentang hutan mangrove di Mangrove Center Tuban yang utama yaitu pengelola sudah tergantikan oleh sumber informasi lainnya sehingga bisa kurang dan berbeda dari kebenaran informasinya.

\subsection{Saran}

1. Pengelola hendaknya lebih aktif dalam memberikan informasi kepada pengunjung dan masyarakat tentang manfaat dan deskripsi hutan mangrove di kawasan Mangrove Center Tuban melalui cara yang mudah dimengerti oleh masyarakat.

2. Pengetahuan masyarakat yang masih menilai hutan mangrove dari aspek ekonomi seperti tempat mencari nafkah dan bahan kayu bakar harus dikurangi, karena bisa saja hutan mangrove tidak diberdayakan sesuai tujuan awal berdirinya Mangrove Center Tuban yaitu sebagai Pusat Pendidikan Lingkungan Hidup.

3. Papan informasi merupakan media yang sangat dibutuhkan masyarakat supaya masyarakat dapat mendapatkan informasi yang berkaitan dengan kawasan Mangrove Center Tuban. Di area kawasan Mangrove Center Tuban masih kurang media ataupun alat komunikasi bagi masyarakat.

4. Batas wilayah hutan mangrove juga dibutuhkan supaya kawasan hutan mangrove tidak rusak yang diakibatkan pemanfaatan oleh masyarakat sehingga hutan mangrove di kawasan Mangrove Center Tuban terlindungi.

\section{Daftar Pustaka}

Badan Pusat Statistika. 2013. Tuban Dalam Angka .BPS.

Moleong, Lexy J. 2007. Metodologi Penelitian Kualitatif. Bandung: PT. Remaja Rosdakarya.

Sutopo H.B. 2010.Metodologi Penelitian Kualitatif Dasar Teori dan Terapannya Dalam Penelitian. Surakarta: Universitas Sebelas Maret.

Walgito, Bimo. 2000. Bimbingan dan Konseling (Studi dan Karier). Penerbit Andi. Yogyakarta. 